УДК 338.45:621

Сакун Л.М., к.е.н., доцент

Sakun L. Candidate of Economic Sciences, Associate Professor https://orcid.org/ 0000-0001-5113-4154

Вєдєніна Ю.Ю., к.е.н., доцент

https://orcid.org/ 0000-0001-7472-6654

Viedienina $\mathrm{Yu}$. Candidate of Economic Sciences, Associate Professor

Тукало К.Ю., студент

Tukalo K. student

\title{
ЗАПРОВАДЖЕННЯ АУТСОРСИНГУ В УКРАЇНІ В УМОВАХ МІНЛИВОГО СЕРЕДОВИЩА
}

\author{
Кременчуцьький національний університет імені М. Остроградського
}

\begin{abstract}
Стаття присвячена аналізу аутсорсингу як одного з методів оптимізації витрат на сучасній фазі розвитку бізнесу. Визначено основні переваги та загрози його застосування, причини запровадження аутсорсингу та оцінено перспективи його розвитку в Україні.

В даний час на практиці бізнес постійно стикається з новими поняттями, які часто називають словами іноземного походження, наприклад, аутсорсинг. Цей термін все частіше використовується для підбору персоналу, побудови команд, регулювання зайнятості, особливо в IT-секторі. Світ сучасних технологій полегшує роботу для людей з будь-якої точки світу, тому процеси аутсорсингу зростають. У невеликому форматі всі пов'язані функції передаються компаніям, що надають послуги, включаючи: бухгалтерський облік, IT програмування, системне адміністрування, юридичні послуги, пошук роботи, логістику, SMM, кол-центри, навчання співробітників тощо.

В даний час ринок аутсорсингу активно розвивається, тому що кожен хоче зменшити людські витрати, матеріальні і витрати часу на виробництво певного товару. Це перспектива аутсорсингу в різних галузях, з урахуванням потреб клієнта. У сучасному світі менеджер не має часу для багатьох процесів, тому їх краще передавати в аутсорсинг. Що раз більше 3'являється галузей і компаній, які надають аутсорсингову послуги в тій чи іншій сфері.

Аутсорсинг дозволяє вирішувати проблеми з підбором, навчанням та утриманням кваліфікованого персоналу, а також з безперервністю бізнес-процесів: заміною працівників на період відпустки, хвороби, навчання, що надаються постачальником послуг. Можливості аутсорсингу: замовник може зосередитись на основних бізнес-функціях; займатися довгостроковим плануванням; вивчати нові технології, нові тенденції на ринку; зменшити витрати на персонал, обладнання на робочому місці, соціальні виплати тощо; оптимізувати оподаткування (оплата аутсорсингових послуг - це валова вартість); займатися улюбленою справою і залишатися самим собою. Використання людського ресурсу - це основа успішної роботи аутсорсингу у світі.

Ключові слова: аутсорсинг, ринок, управління, конкурентні переваги, фрілансер, стійкість підписмства.
\end{abstract}

\section{INTRODUCTION OF OUTSOURCING IN UKRAINE IN THE CONDITIONS OF A CHANGING ENVIRONMENT}

\author{
Kremenchug National Ostrogradsky University
}

Article is devoted the analysis of outsourcing as one of the methods of optimization of expenses at the modern phase of business development. The main advantages and threats of its application, the reasons for the introduction of outsourcing and the prospects of its development in Ukraine.

Currently, the practice of business is constantly faced with new concepts, often called ' words of foreign origin, for example, outsourcing. This term is increasingly used for recruitment, team building, regulation of employment, especially in the it sector. The world of modern technology makes work easier for people from anywhere in the world, therefore, the processes of outsourcing increasing. In a small format all the related functions are transferred to companies that provide services, including: accounting, IT, programming, system administration, legal services, job search, logistics, social media marketing, call centers, employee training and so on. 
Currently, the outsourcing market is actively growing, because everyone wants to reduce the human costs, material costs and time for manufacturing a certain product. Is the prospect of outsourcing in various industries, tailored to the needs of the client. In the modern world, the Manager doesn't have time for many processes, so it is better to transfer to outsourcing. Once more and more industries and companies that provide outsourcing services in a particular area.

Outsourcing allows to solve problems of selection, training and retention of qualified staff and continuity of business processes: the replacement of employees during leave, sickness, training, provider. Outsourcing capabilities: The customer can focus on core business functions; engage in long-term planning; learn new technologies, new market trends; reduce staff costs, workplace equipment, social benefits, etc; optimize taxation (paying for outsourcing services is a gross cost); to do your favorite thing and be yourself. The use of human resources is the basis for successful outsourcing in the world.

Keywords: outsourcing, market, management, competitive transfers, freelancer, enterprise sustainability.

Постановка проблеми у загальному вигляді та іï зв'язок 3 важливими науковими і практичними завданнями. У сучасній фазі економічного розвитку, що характеризується постійним зростанням конкуренції та нестабільністю всіх сфер діяльності, компанії, що бажають оптимізувати свою діяльність та зменшити кількість виконуваних функцій, стикаються з необхідністю постійної та налагодженої співпраці 3 іншими суб'єктами господарювання. Важливо також звернути увагу на посилення міжнародного розподілу праці. Спеціалізації країн і компаній, особливо бізнес-процеси, набувають все більшого значення для забезпечення їх довгострокової життєздатності та конкурентоспроможності. Сьогодні аутсорсинг - це одна з найпопулярніших моделей бізнесу.

Аналіз останніх досліджень, у яких започатковано вирішення проблеми. Вагомий внесок у дослідження та розкриття сутності цієї концепції, обгрунтування переваг та недоліків, які вона надає, зробили сучасні зарубіжні вчені, включаючи Анікін Б.А., Календжан С.О., Хейвуд Дж.Б та інші. Теоретичні та прикладні аспекти створення та розвитку аутсорсингових форм ділової діяльності знайшли відображення в науковій роботі таких вітчизняних вчених, як Григорак Ю., Зозульов О. В., Маноленко О. В. та інші.

Метою статті $\epsilon$ дослідження процесу аутсорсингу та виявлення особливостей його застосування та ідентифікувати відмінності аутсорсингу та постачання товарів та послуг, а також переваги та загрози від застосування аутсорсингу в діяльності вітчизняних підприємств.

Виклад основного матеріалу дослідження 3 обгрунтуванням отриманих наукових результатів. Слово «аутсорсинг» походить від англійського „оutsourcing”, що в перекладі означає «залучення зовнішніх ресурсів». Такий формат бізнесу буде ефективний, коли компанії недоцільно постійно тримати великий штат спеціалістів, а вигідніше для вирішення певних задач користуватися послугами зовнішньої спеціалізованої організації. В світі аутсорсинг поширений в багатьох сферах бізнесу. Сучасні спеціалісти вважають аутсорсинг перспективною бізнес-технологією, використання якої може привести до підвищення якості та зниження витрат [1]. Аутсорсинг, тобто передача сторонній фірмі певного виду діяльності, яка раніше виконувалася в рамках даної організації, має як позитивні, так і негативні риси. До негативних ознак можна віднести: незнання організації специфіки бізнесу клієнта; підвищення ризику "розповсюдження" інформації; збільшення витрат на оплату наданих послуг.

До позитивних особливостей аутсорсингу належать: економія витрат; виконання роботи більш якісно, оскільки воно доручено спеціалізованій компанії; передача ризику постачальнику; можливість концентруватися на основній діяльності; отримання якісних послуг та інновацій. За статистикою, аутсорсинг стає все більш популярним. Зокрема, кількість фрілансерів та службовців, які працюють 3 дому, постійно збільшується. 
Незалежні працівники є основою для прийняття рішення про доцільність аутсорсингу. На думку експертів, кількість фрілансерів, зокрема, зросла у 2015 році. За даними Elance, Україна посідає четверте місце у світі за рівнем доходів серед фрілансфахівців. На думку галузевих експертів, до 2021 року близько 60\% світового ринку праці будуть позаштатними. За даними компанії, сьогодні близько 15000 українців працюють позаштатно для іноземних компаній із середньою заробітною платою 16 доларів на годину. За статистикою, найбільша кількість фрілансерів з України задіяна в IT (93\% 22 долари США / годину), менша частина присвячена копірайтингу, перекладу, а ще менше - фінансам, аудиту, адміністрації та менеджменту [2]. С дві основні та найголовніші причини використання аутсорсингу на підприємствах. Перша - це виявлення, аналіз та вирішення проблемних питань компанії, до яких керівники та працівники просто звикли або готові визнати проблему через зусилля зекономити чи небажання виявляти свою неспроможність у справі. Друга причина - зменшити витрати на розширення діяльності шляхом залучення експертів, інструментів та приміщень, які наразі відсутні в інших компаніях (аутсорсинг). Як результат, компанія зводить дефіцит виробництва до мінімуму, налагоджує зв'язок із зовнішнім ринком i, в реальному вираженні, економить час i гроші на пошук поточних i довгострокових активів, включаючи персонал. Тому цей вид діяльності здатний вирішити подібні проблеми за допомогою кваліфікованої допомоги спеціалістів та компетентних фахівців.

Ще однією важливою причиною аутсорсингу вітчизняних компаній є фінансовоекономічна криза. Підприємства не можуть утримувати самостійно кваліфікованого працівника і відповідно змушені наймати його ззовні, або працівник компанії стає фрілансером, і крім надання тих самих послуг для попереднього працедавця, виконує схожі функції і для інших компаній. Що стосується адміністративних витрат та оптимізації податків, а також неповної зайнятості окремих працівників, які наймані ззовні, то в діяльності організацій будуть досягнуті значні заощадження. Згідно 3 оцінками, суб'єкти господарювання, що перебувають у сфері аутсорсингу, передавали в оренду окремі функції або допоміжні дії, щоб заощадити від 10 до 40\% [3]. 3 іншого боку, більш досвідченому працівнику вигідніше сидіти вдома без витрат на поїздки роботодавця, обслуговувати більше клієнтів та отримувати винагороду.

Ще однією причиною аутсорсингу $є$ активізація розвитку інформаційних технологій, спрощення доступу до Інтернету, прискорення зв'язків 3 Інтернетом, зменшення соціально-економічних бар'єрів між країнами та регіонами, посилення глобалізації тощо. Як результат, віртуальні підприємства виникають у різних сферах діяльності не тільки в галузі IT, але й створюють віртуальні університети у вигляді освітніх платформ, віртуальних лабораторій, дистанційного навчання 3 практичною та лабораторною реалізацією у зручному для студента місці. Аутсорсинг та процес постачання ресурсів, матеріалів, готової продукції постачальнику чи субпідряднику повинні бути чітко відокремлені. Як зазначає Роберт Хендфілд, реструктуризація бізнеспроцесів компанії обов'язково повинна відбуватися в процесі аутсорсингу, і лише певні функції з працівниками або без них будуть передані під час передачі постачальнику, як правило, у малих компаніях [4]. Вони часто хочуть зменшити свій репутаційний ризик (у випадку розробки інноваційної ідеї або шару високого ризику) або зменшити витрати. Основні відмінності між аутсорсингом та доставкою продукції для різних функцій узагальнені в таблиці 1.

Мета застосування аутсорсингу - використання передових бізнес-технологій і ноу-хау для завоювання та утримання конкурентних переваг в умовах загострення відносин між організаціями, що передають і приймають на себе виконання окремих видів діяльності на основі укладених довгострокових угод. Рішення щодо аутсорсингу - це 
складне завдання, яке зачіпає стратегічні інтереси і тому належить до компетенції вищого керівництва компанії.

Таблиця 1

Відмінність аутсорсингу та доставки товарів та послуг

\begin{tabular}{|c|c|c|}
\hline Ознаки & рсинг & \\
\hline Ціль & $\begin{array}{l}\text { Підвищення } \quad \text { конкурентоспроможності через } \\
\text { оптимізацію та реорганізацію бізнес-процесів }\end{array}$ & $\begin{array}{l}\text { Пошук оптимальних варіантів } \\
\text { ціна/якість }\end{array}$ \\
\hline Часові в & $\begin{array}{l}\text { Домінування середньотермінового або } \\
\text { довготермінового періоду, достатнього для } \\
\text { реструктиризації або перебудови бізнес-процесів }\end{array}$ & $\begin{array}{l}\text { Домінування } \\
\text { короткотермінового періоду } \\
\text { для оптимізації поставок }\end{array}$ \\
\hline $\begin{array}{c}\text { Критерії } \\
\text { оптимізації }\end{array}$ & $\begin{array}{l}\text { Скорочення транзакційних та умовно-постійних } \\
\text { витрат }\end{array}$ & $\begin{array}{l}\text { Скорочення } \quad \text { передусім } \\
\text { умовно-змінних витрат }\end{array}$ \\
\hline $\begin{array}{l}\text { Функціональний } \\
\text { вплив }\end{array}$ & $\begin{array}{l}\text { Стратегічний, який поширюється на усі бізнес- } \\
\text { процеси }\end{array}$ & $\begin{array}{l}\text { Забезпеченість } \\
\text { бізнес-процесів }\end{array}$ \\
\hline Організу & $\begin{array}{l}\text { Побудова із аутсорсерами спільних узгоджених } \\
\text { бізнес-процесів для досягнення ключової переваги }\end{array}$ & $\begin{array}{l}\text { Отримання окремих продуктів } \\
\text { від постачальників товарів та } \\
\text { послуг }\end{array}$ \\
\hline $\begin{array}{c}\text { Рівень } \\
\text { ефективності }\end{array}$ & $\begin{array}{l}\text { Досягнення високого рівня інтеграції бізнес- } \\
\text { процесів та мінімізації рівня взаємодії }\end{array}$ & $\begin{array}{l}\text { Гнучкість та низька вартість } \\
\text { послуг із постачання }\end{array}$ \\
\hline $\begin{array}{l}\text { Підтримка } \\
\text { партнера }\end{array}$ & $\begin{array}{l}\text { Надання необхідних ресурсів аутсорсиру, зокрема } \\
\text { технологій виробництва }\end{array}$ & $\begin{array}{l}\text { Можлива лише фінансова у } \\
\text { вигляді авансів або кредитів }\end{array}$ \\
\hline
\end{tabular}

Насправді це рішення є вибором між власним виробництвом та придбанням послуг «на боці» і пов'язане з аналізом фактичної ситуації в компанії та можливих ризиків аутсорсингових проектів. Можна виділити основні переваги та загрози аутсорсингу на підприємствах (табл. 2).

Таблиця 2

Переваги та загрози використання аутсорсингу

\begin{tabular}{|c|c|}
\hline Переваги & Загрози \\
\hline $\begin{array}{l}\text { Підвищення } \\
\text { компанії }\end{array}$ & \multirow[t]{2}{*}{ Невелика кількість аутсорсингових компаній на ринку } \\
\hline Розподіл та зменшення ризиків & \\
\hline $\begin{array}{l}\text { Зниження собівартості функцій, делегованих } \\
\text { виконавцю }\end{array}$ & $\begin{array}{l}\text { Втрата контролю над власними ресурсами та певною } \\
\text { частиною виробництва }\end{array}$ \\
\hline Підвищення надійності та якості & Зниження продуктивності праці робітників \\
\hline Зосередження на основних цілях компанії & Збільшити витрати на передачу менших функцій \\
\hline $\begin{array}{l}\text { Доступ до знань, додаткових ресурсів та } \\
\text { нових технологій. }\end{array}$ & Зниження якості товарів та послуг \\
\hline Зниження експлуатаційних витрат & Загроза розбійного нападу сторонньої фірми \\
\hline $\begin{array}{l}\text { Збільшення швидкості виходу товарів на } \\
\text { ринок }\end{array}$ & Ризик витоку ділової інформації компанії \\
\hline Удосконалення системи управління & Нерозвинена культура взаємодії компанії та аутсорсера \\
\hline Скорочення витрат на навчання персоналу & Залежність від одного постачальника \\
\hline $\begin{array}{l}\text { Можливість розміщення замовлень на } \\
\text { виробництво комплектуючих за кордоном за } \\
\text { нижчими цінами, ніж вітчизняні та кращої } \\
\text { якості }\end{array}$ & Навчайте чужих експертів замість власних \\
\hline $\begin{array}{l}\text { Зростання сегмента ринку, який охоплює } \\
\text { компанію }\end{array}$ & $\begin{array}{l}\text { Чітке планування виробництва товарів та закупівля } \\
\text { необхідних матеріалів }\end{array}$ \\
\hline $\begin{array}{l}\text { Зниження собівартості функцій, переданих } \\
\text { аутсорсеру }\end{array}$ & 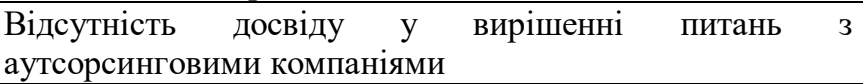 \\
\hline
\end{tabular}


3 огляду на проаналізовані проблеми розвитку національної економіки, можна зробити висновок, що український аутсорсинг має значний потенціал для ефективного функціонування. Перспективи розвитку цієї сфери діяльності включають:

- аутсорсинг може значно зменшити рівень безробіття в країні та за кордоном, а також зменшити відтік висококваліфікованих фахівців із країни, яка шукають роботу в економіках зарубіжних країн;

- якість українського IT-аутсорсингу є високим рівнем, що може забезпечити зростання національної економіки, якщо умови сприятливі для розвитку;

- аутсорсинг може значно знизити витрати на виробництво, маркетинг, логістику та інші сфери діяльності;

- аутсорсинг дозволяє зменшити зайве навантаження з психологічної та фізичної точки зору та звернути увагу на основні аспекти управління бізнесом.

Висновки. Незважаючи на всі переваги, аутсорсинг не $\epsilon$ широко поширеним в Україні. На відміну від західних країн, в нашій країні недостатньо компаній, які надають цю послугу, особливо в регіонах. Український аутсорсинг зараз переживає період накопичення досвіду, і його професійне використання як спільного інструменту в маркетингу середнього та малого бізнесу буде лише через 6 - 10 років. Ще одна причина, чому підприємці не використовують аутсорсинг, - це страх розповсюдження ділової інформації. Але необхідність бізнесу часто змушує їх ризикувати. Завдяки аутсорсингу, підприємства можуть не лише значно зменшити виробничі витрати та покращити якість продукції, а й забезпечити умови для сприяння економічного зростання, зокрема, створюючи робочі місця для українських фахівців-аутсорсерів.

\section{Список бібліографічного опису}

1. Плюси й мінуси аутсорсингу маркетингових послуг: думка експертів. Міжнародна Маркетингова Група України. URL: http://www.marketing-ua.com.

2. Україна в п’ятірці країн, де масово вербують фрілансерів. URL: http://www.kadrovik.ua.

3. Поливана Л. А. Ситуаційний підхід до визначення терміна “аутсорсинг” Науковий вісник Полтавського університету економіки і торгівлі. 2014. №2(64). С. 139-145.

4. Handfield R. A brief history of outsourcing.URL: https://scm.ncsu.edu.

5. Бравар Ж. Л. Ефективний аутсорсинг. Баланс Бизнес Букс. 2007. 288 с.

\section{References}

1. Plyusy y minusy aut·sorsynhu marketynhovykh posluh: dumka ekspertiv. Mizhnarodna Marketynhova Hrupa Ukrayiny. URL: http://www.marketing-ua.com. [in Ukrainian]

2. Ukrayina v p"yatirtsi krayin, de masovo verbuyut' frilanseriv. URL: http://www.kadrovik.ua. [in Ukrainian]

3. Polyvana L. A. Sytuatsiynyy pidkhid do vyznachennya termina "aut·sorsynh" Naukovyy visnyk Poltavs'koho universytetu ekonomiky i torhivli. 2014. No 2(64). pp. 139-145. [in Ukrainian]

4. Handfield R. A brief history of outsourcing.URL: https://scm.ncsu.edu

5. Bravar, Zh. L. Efektyvnyy aut·sorsynh. Balans Byznes Buks. 2007. 288 p. [in Ukrainian]

Дата подання публікації 02.06.2020 